\title{
Purification and Properties of Trehalase(s) from Neurospora ${ }^{1,2}$
}

\author{
F. P. HILI, AND A. S. SUSSMAX \\ From the Department of Botany, Tniversity of Michigan, Inn Abor, Wichigan \\ Received March 18, 196:3
}

\begin{abstract}
Trehalase has been obtained in crystalline form from the mycelium of Neurosperc carass. During elution from the first pass through a l)liAE-cellulose column, $t w$, peaks with trelialase activity were obtained. When the first of these was rechromiltographed on IDEAE-cellulose, two more major peaks were found. The enzymors of these fractions were compared and found to be similar in substrate specificity, response to inhibitors, pH optima, and Michalis constants. However, small difference in the rate of inuetivation of these enzymes at $50^{\circ}$ were detceted.
\end{abstract}

\section{INTRODUCTION}

The disaccharide trehalose has been found in organisms as diverse as microbes, rertebrates, invertebrates, ferns, and phanerogams (2:3). In several instances, its accumulation and utilization are associated with resistant stages like diapause in insects (32), brine-shrimp eggs (5), and fungus spores $(2,15,18,27)$.

As early as 1904 , Bourquelot and Herissey (4) were able to demonstrate that the disappearance of trehalose in fungi coincided with the appearance of trehalase, an enzyme whose activity had first been demonstrated in 1893 (3). Since that time this enzyme has been found in bacteria $(1,11)$, other fungi $(10,20,22,30)$, insects $(12-14$, $16,24,33)$, oysters (7), fish (31), hog intestinal mucosa (8), and higher plants $(6,10,29)$. Despite their ubiquity, however, the physiological role of the sugar and enzyme is not known.

One suggestion is that their role in the case of ascospores is the provision of energy for germination, whereas lipid serves this purpose in dormant spores (26). Inasmuch as tichalose accumulates to the extent of $1.5 \%$ in such dormant spores, the treatment which permits germination to occur must

t This work was supported by grant (i-1933t from the National Science Foundation.

" The authors are indehted to Mr. Fred Eilers for technical assistauce. trigger a means through which the sugar is utilized. Such a means may be the enzyme trehalase. Therefore, the properties of trehalase from Nornspora were determined in these experiments, as a prelude to the study of the regulatory role postulated above for this enzyme.

\section{METHOIS}

Protein was measured as describal in Jenry et al. (19) using bovine serum alhumin is at standard.

Trehalase antivity was measured, muless other'wise stated, in the following maner: $1 \mathrm{ml}$. sodium phosphate buffer $0.05 \mathrm{H}, \mathrm{pH} 5.6$, here: it te referred to as the "standard huffer," 1.0 ml. trehalose dihydrate in standard buffer containing jo $\mathrm{mg} . / \mathrm{ml}$., and $0.1 \mathrm{ml}$. enzyme in a total volume? of $2.1 \mathrm{ml}$. of standard buffer. These reactants were incubated for $30 \mathrm{~min}$ at $37^{\circ}$, and the reaction was stopped by boiling for 5 min. Reducing sugar was measured as gluense by the method of Somogri (25). 1)ptinal densities of all assays were measured in a Klett. Summerson ablorimeter with a $N_{n}$. jt filtex. A minimum of triplicate samples was nocl in all experiments.

In experiments where the substate specifieity was determined, the glucose released Wats measured by the glucose oxidase methol ifi, modifiel as described below. One milliliter of suls:trate, in standard buffer, and adjusted to grie ghouse equivalents identical to trohalose, am $0.1 \mathrm{ml}$. enzyme were made up tos a total wolume of $2.1 \mathrm{mi}$ in standard bulfer and incubated at $37^{\circ}$ for 30 min. The reaction was stopped by buling for ; min. Cilueose oxidase and chromogen provided 


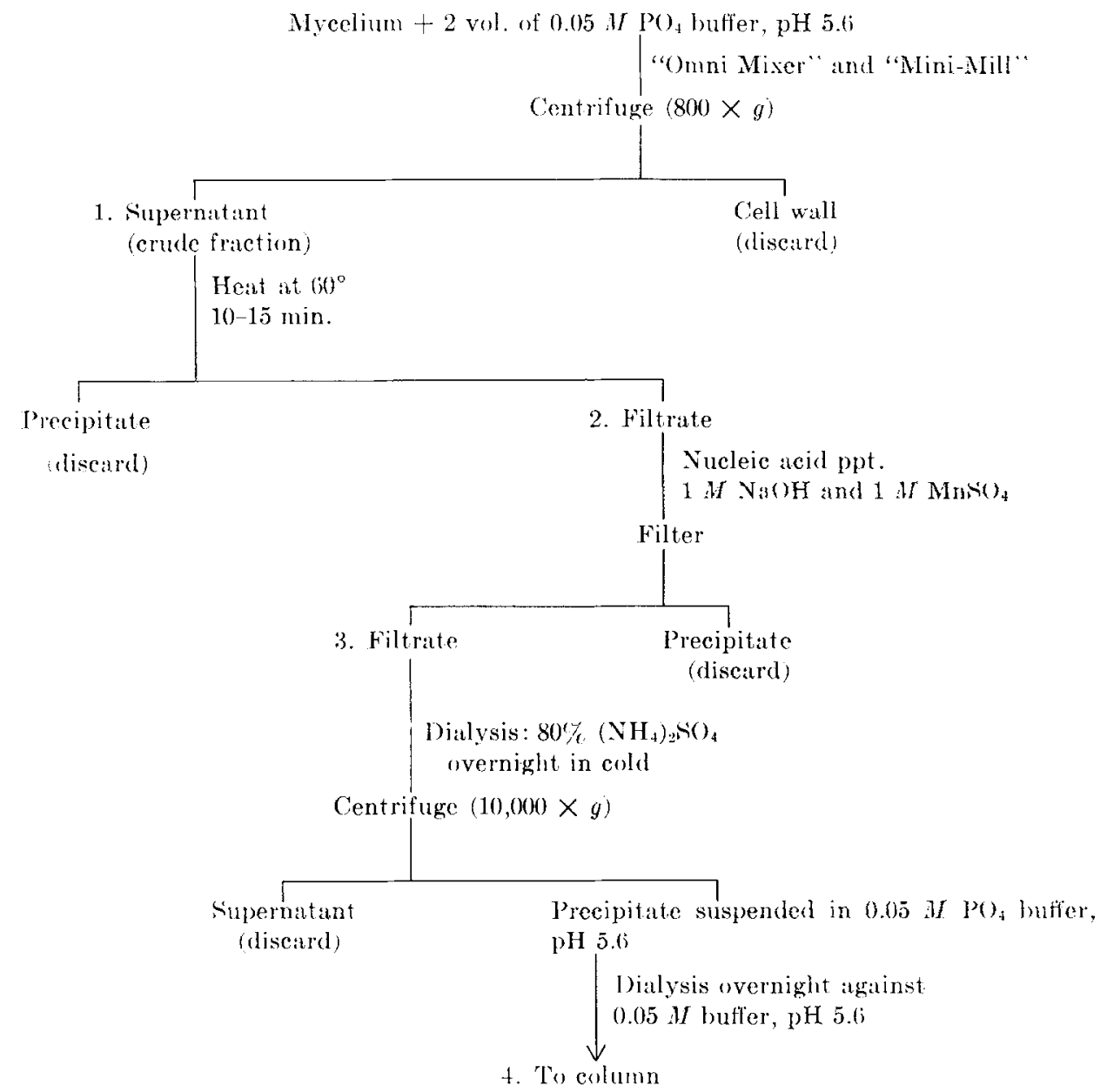

Fici. 1. Protocol of extraction of trehalases from Neurospora mycelium. Conditions of assay described in text.

with the "Glucostat reagent" (purchased from Worthington Biochemical Corp., Freehold, X. J.) were added, and the entire reaction mixture was incubated for $30 \mathrm{~min}$., unless otherwise indicated, at $3 r^{\circ}$. The reaction was stopped by adding $0.1 \mathrm{ml}$. of $+.1 \mathrm{HCl}$ per tube. The color formed was read at $400 \mathrm{~m} \mu$ in a Beckman DU spectophotometer.

The glucose oxidase and chromogen were prepared in the following manner: The enzyme and chromogenic agent were 22 and $44 \%$, respectively, of the concentrations suggested by the company. These changes were introduced to reduce the high background color which was obtained when the amounts recommended by the supplier were used. All standards, controls, and reaction mixtures were assayed at these concentrations.

One unit of activity is defined as that amount of enzyme that will produce $1 \mu \mathrm{g}$. of reducing sngar, measured as glucose, in $30 \mathrm{~min}$. at $37^{\circ}$ in standard buffer.

\section{Preparation of the Exzyme lixtract FROM NEUROSPORA}

A conidial suspension of an "inositol-less" strain of Neurospora crassa, designated as 89601-A, was introduced into each of three 9-1. carboys filled with 6-1. of sterile medium. The medium consisted of $50 \mathrm{mg}$./1. inositol, $2 \%$ Vogel's (28) salt solution, and $2 \%$ sucrose. The carboys were sparged with compressed air during a growth period of 5 days at $25^{\circ}$. The mycelium was harvested by filtering through coarse muslin, washed with twice its volume of distilled water, pressed as dry as possible with paper towels, and immediately frozen. Total yield of mycelium per liter of medium was $a .40 \mathrm{~g}$. (wet weight). After 26 days in the frozen condition, the mycelium was thawed and the enzyme wiss extracted according to the protoeol in Fig. 1.

The mycelium was macerated by grinding in 
twice its volume of standard buffer for $4-40$-see. periods, with a 5 -min, cooling interval, in an "Ommi-Mixer" whose cup was immersed in ice. The resulting brei was further homogenized in a Gifford-Wood "Mini-Mill." 'This was aceomplished by placing $50 \mathrm{ml}$. brei with $50 \mathrm{ml}$. glass beads (Minnesota Mining and Manufacturing Co. Super-Brite pavement markers) in the "MiniMill" cup and grinding for 3 min. The rotor was spaced $2.5 \mathrm{~mm}$. from the stator, and the rheostat was set at 100 . The cup was always immersed in ice during this operation.

\section{Plirificatiox OF Trehalase ON Colcmsi of DEAE-CELLTLOSE}

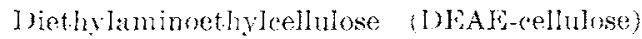
(purchased from California Corporation for Bioclemical Research, Los Angeles (33, Calif.) was prepared for use as follows: $100 \mathrm{~g}$. of the dry powder was allowed to sink into 41 . of $0.5 \mathrm{~N} \mathrm{NaOH}$. After settling, the I)HAE-cellulose was washed with 10 I. of demineralized water in 1-l. aliquots. Each time the "fines" were siphoned ofi. The DEAE-cellulose slurry was then wasled with 41 . of standard bulfer lefore being placed into a columm. The column was formed by allowing enough slurry to settle by gravity until a bed $2.5 \mathrm{~cm} . \times 30 \mathrm{~cm}$. Was made. The column was furthre washed with 21 . of standard buffer before the comcentrated enyme was applied. The enzyme was applied to the column and washed with 1 1. of standard buffer. A gradient elution system was established by placing 11 of standard buffer in the mixer and 11 . of standard buffer supplemented with $1.1 / \mathrm{NaCl}$ in the reservoir. The column was adjusted to deliver $1 \mathrm{drop} / \mathrm{sec}$.

The enzyme from fractions 8 and 11 was diluted with standard buffer so as not to produce over 800 $\mu \mathrm{g}$. glucose/ml. enzyme. The enzyme thus diluted was used in inhibitor, H-ion concentration and heat-stability assays.

\section{Hent Stamithy}

Fingyne aliquots, $3.5 \mathrm{ml}$, were plared in test tubes inmersed in a water bath at the appropriate temperature. At the designated time intervals 0.1-ml. aliquots were withdrawn, placed in test. tubes, plunged into an ice bath, and assayed for glueose.

\section{INhibitor Studies}

The enzyme in $0.1-\mathrm{ml}$. aliquots was placed in the presence of inhibitors at various encentrations for $30 \mathrm{~min}$. at $37^{\circ}$. After incubation in the presence of the inhibitor, trehaluse was alded and the reaction mixture was incubated for an adolitional $30 \mathrm{~min}$. at $37^{\circ}$ and assuyed for glucose.

\section{H-Ion Coxcextration}

Sodium phosphate buffer, $0.05 \mathrm{H}$, was adjusted to various $H$-ion concentrations with a model $G$ Beekman $\mathrm{pH}$ meter. The substrate was dissolved in demineralized water. Incubation of the reacetions mixture and assay for glueose was performed as previously described. Although the hulfer capacity of phosphate is low in parts of the range $\mathrm{pH} 3.5-5.5$, there was no change in the pH during the experinent.

\section{RESULTS}

The elution pattern of trehalase, shown in Fig. 2, from a crude extract applied to a DFAE-cellulose column suggested the presence of two different proteins that show trehalase activity. Trehalase from the first peak, between volunes 500 and $800 \mathrm{ml}$, was reprecipitated in $80 \%\left(\mathrm{NI}_{4}\right)_{-} \mathrm{SO}_{4}$, dialyzed against standard buffer, and reapplied to the column. The elution pattern from the second application to a DEAL:cellulose column indicated that fractions 7 and 11 came off at approximately the same place. On the other hand, fraction 8 was cluted much sooner than was fraclion 12, suggesting a difference in the proteins of these two samples.

Another difference in behavior is shown in the heat stabilities (Figs. :3a and $: 36$ ), although the differences are not very pronounced. It $50^{\circ}$ fraction 8 (Fig. :3a) lost activity slightly whereas fraction 11 (F"ig. 36) increased in activity. It the other temperatures, however, the patterus are quite similar. The half-life of both enzymes is similar, that for fraction 8 being 4 min. at $70^{\circ}$ and that for fraction 11 being $: 3$ min. at $70^{\circ}$.

A summary of the purification achieved in the steps outlined in I"ig. I is provided in Table I. The greatest purification of trehalase attained on DEAL-cellulose was approximately 250-fold as shown in Table I. In further attempts to purify the enzyme (fraction 11) by ethanol fractionation, it was found that it erystallized, upon the addition of enough absolute ethanol to make a $40 \%$ solution, when allowed to stand in the deep freeze overnight. The crystals were collected by centrifugation or filtration over a Büchner fumel. ['pon a secies of three recrystallizalions, activity was found to remain in the crystals. 


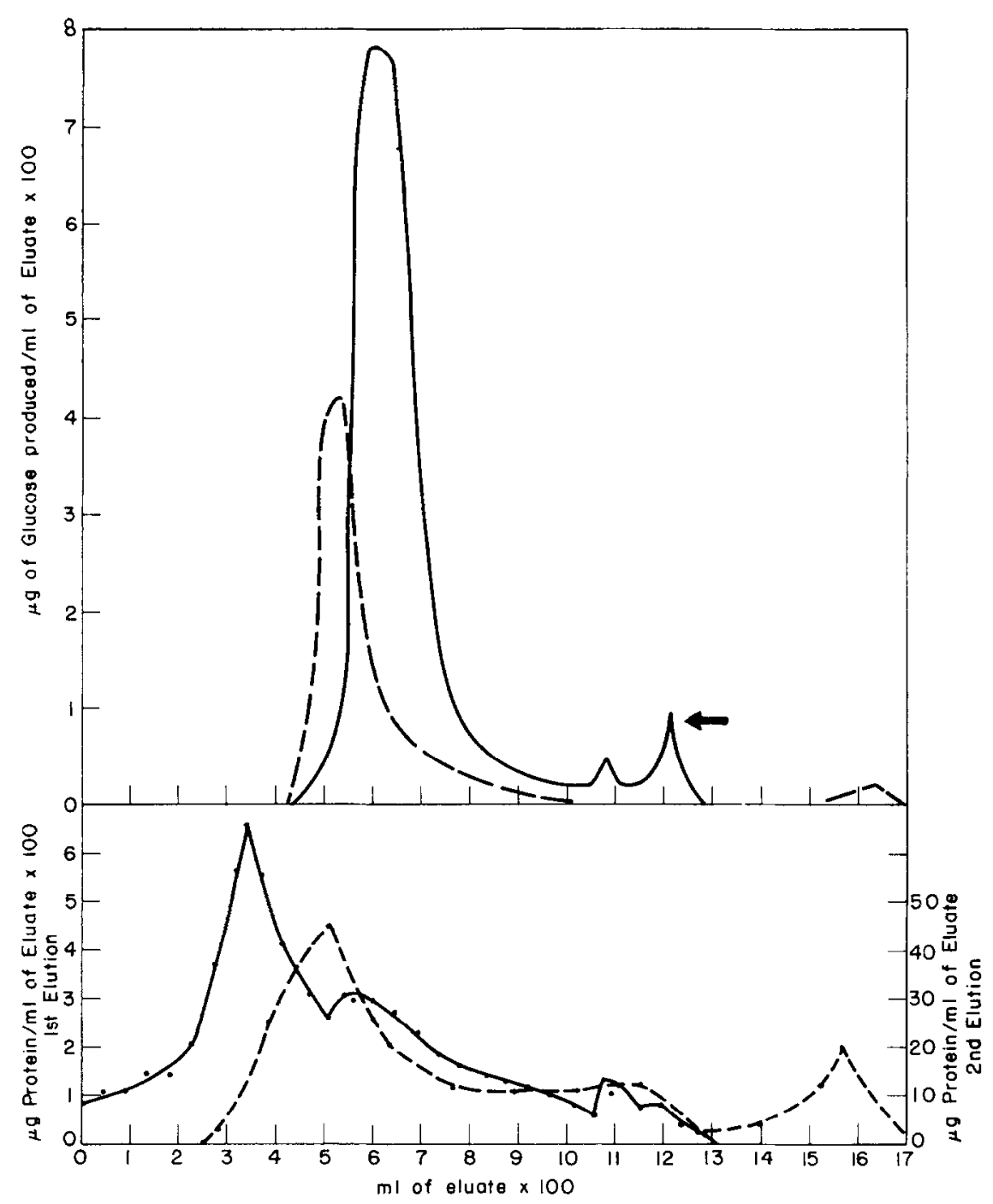

Fig. 2. Upper curves: gradient elution pattern of Neurospora trehalase(s) from a 13EAE-cellulose column. The solid line represents the elution pattern of trehalase from a partially purified extract after one passage through the column. The two peaks are numbered fractions 7 and 8 (Table I). The eluates were collected in $9.2 \mathrm{ml}$. aliquots. No activity was detected until ca. $435 \mathrm{ml}$. irrigant had passed through the column. The dotted line represents the elution pattern of trehalase activity after passage of the enzyme from the first peak between 505 and $785 \mathrm{ml}$, after it had been reconcentrated, dialyzed, and reapplied to the same column. The two major peaks are numbered fractions 11 and 12 (Table I). The column had previously been cleansed of protein with $0.5 \mathrm{~N} \mathrm{NaOH}$ and reequilibrated with standard buffer. The 2nd elution was collected in $25.5-\mathrm{ml}$. aliquots. See text for an explanation of the gradient system. Arrow indicates peak from which fraction 8 was derived. Lower curves: gradient elution pattern of protein recovered from Neurospora extracts on DEAE-cellulose. The solid line describes the elution pattern of the 1st application and the dotted line corresponds to that of the 2nd application.

Michaelis constants $\left(K_{s}\right)$ were derived as a means of comparing the trehalases from the several fractions. A comparison between trehalases recovered from two different extractions is given in Table II. No differences are obvious.

The substrate upon which fractions 8 and 11 is active includes only trehalose (Table 

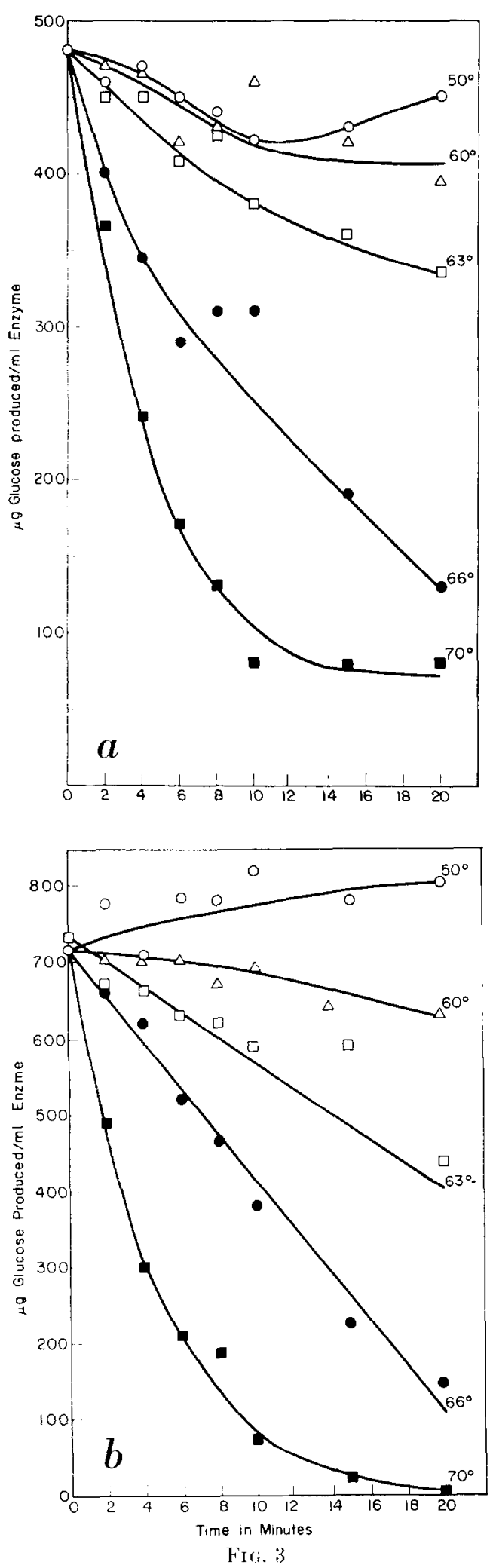

III). Fraction 12 showed more activity (m) sucrose, melibiose, and cellobiose than did the other two fractions. However, it should be noted that the specific activity of fraction 12 was mueh lower than those of the other fractions (Table II) so that comtaminant proteins could have been responsible for the cross specificity. Moreover, glucose oxidase has traces of maltasc, trehalase, and invertase, as indicated by high values for the respective sugar controls, so that, mider the conditions of the assay, no appreciable utilization of sugars except trehalose is demonstrated with purified trehalase from fractions 8 and 11 .

The following inhibitors were without appreciable effect on the trehalase activities of either fraction 8 or fraction 11: $\mathrm{Na} \mathrm{N}_{3}$, $\mathrm{Na}$ arsenate, $\mathrm{CuSO}_{4} \cdot 5 \mathrm{H}_{2}(\mathrm{O})$, gluconic $\delta$ lactone, urea, $\mathrm{NiCl}_{2} \cdot 6 \mathrm{H}_{2} \mathrm{O}$, aniline, $\mathrm{Nal}$, and indoacetate. All inhibitors were used at concentrations which ranged from $1 \times$ $10^{-5}$ to $1 \times 10^{-2} M$ except $\left(\mathrm{CuSO}_{4} \cdot 5 \mathrm{jH}_{2} \mathrm{O}\right.$ which was used at $1 \times 10^{-5}$ to $1 \times 10^{-3}, 11$.

The $\mathrm{pH}$ optima shown in lig. 4 are similar for both enzymes. The maximum rate at which glucose formed was found to be at $\mathrm{pH}$ 5.5 with a sharp decline in rate toward more alkaline conditions.

\section{DISCLTSEION ANI) CONCLUSIONS}

The properties of the trehalases from Neurospora resemble those of the trehalases from other sources in several respects. Thus, the Michaelis constants of the enzyme from yeast (6), seeds of Plantago (6), June bugss (6), silkworms (24), wax moths (16), and blowflies (13) range from $1.3 \times 10^{4} \mathrm{MI}$ to $9 \times 10^{-4} \mathrm{I} /$; the values obtained for Neurospora are intermediate. However, the Michaelis eonstant of the trehalase from pig intestinal mucosa is : $\times 10^{-3} \mathrm{M}$ and deviates markedly from these values (9). In general, where purified trehalases have been used, trehalose is the only substrate that is utilized $(9,13,16,24) . \mathrm{NI}$ though the enzyme from June bugs was partially purified (6), it retained activity on maltose and sucrose but further work

Fin. 3. Heat stability of Veurospore trehalase a. Hinzyme from fraction 8 . b. Finzyme from frac1.ion 11. Conditions of assay are described under Methods. 
TABLE I

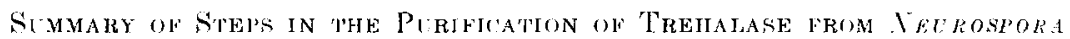

Conditions of assay are described in text. Steps are numbered to coincide with those numbered in Figs, 1 and 2 .

\begin{tabular}{|c|c|c|c|c|c|}
\hline Fraction & 'Total artivity & Total Irotein & $\begin{array}{l}\text { Recovery } \\
\text { artivity }\end{array}$ & $\begin{array}{l}\text { Specific: } \\
\text { activity }\end{array}$ & $\begin{array}{l}\text { Purification } \\
\text { factor" }\end{array}$ \\
\hline 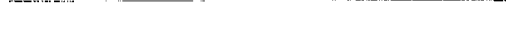 & tunits & $m g$. & $\%$ & & \\
\hline 1. Crude & $4,083,700$ & $8.984 \times 10^{3}$ & $(100)$ & 454 & -- \\
\hline 2. After heat treatment & $3,65+, 000$ & $4.891 \times 10$ & 89.4 & 747 & 1.6 \\
\hline 3. After nucleic acid treatment & $3,536,000$ & $3.648 \times 10^{3}$ & 80.5 & 969 & 2.1 \\
\hline 4. After buffer dialysis & 2,$236 ;, 600$ & 637 & 54.7 & 3,510 & 7.7 \\
\hline 5. 1st application to column & $2,110,000$ & 601 & 54.7 & 3,510 & 7.7 \\
\hline $\begin{array}{l}\text { (i. Recovered from } 1 \text { st column elu- } \\
\text { tion }\end{array}$ & $1,+162,890$ & $13: 3$ & 35.8 & $10.9 \%$ & 24.1 \\
\hline 7. Peak 1 : at the crest of the peak & $\begin{array}{c}\text { At vol. } 598 \mathrm{ml} \\
71,760\end{array}$ & 2.708 & $-\cdots$ & 20,490 & 58.3 \\
\hline 8 . Peak $2:$ at the crest of the poak & $\begin{array}{c}\text { At. vol. } 1210.0 \mathrm{ml} \text {. } \\
990\end{array}$ & 0.6699 & $-\cdots$ & 14,798 & 32.6 \\
\hline $\begin{array}{l}\text { 9. Applied to 2nd column. Act. } \\
\text { eluted in Jeak } 1 \text {. }\end{array}$ & 705,600 & 17.940 & - & 34,331 & $86 i .1 i$ \\
\hline 10. Peak 1, 2nd elution & $\begin{array}{c}\text { At vol. } 430-842 \mathrm{ml} \\
\qquad(605,833)\end{array}$ & 10.574 & $16 . \tilde{5}$ & 62,023 & 136.6 \\
\hline $\begin{array}{l}\text { 11. Peak 1, 2nd elution. At } \\
\text { the crest of the peak }\end{array}$ & $\begin{array}{c}\text { At vol. } 535.0 \mathrm{ml} \\
107,100\end{array}$ & 0.928 & -- & $115,+109$ & $25+.2$ \\
\hline $\begin{array}{l}\text { 12. Peak } 2 \text {, 2nd elution. At the crest } \\
\text { of the peak }\end{array}$ & $\begin{array}{c}\text { At vol. } 1640.0 \mathrm{ml} \\
5,100\end{array}$ & 0.515 & $\cdots-$ & 10,873 & 23.9 \\
\hline
\end{tabular}

a Compared to the specific activity of the crude extract.

will be necessary before its broad specificity can be accepted.

If trehalase is involved in the germination of Newrospora ascospores, it might be expected to survive the high temperatures ( $60^{\circ}$ for $5-30$ min.) required to break the dormancy of these cells. $A$ s can be seen in Figs. $3 a$ and $b$, the trehalases of the Neurospora mycelium survive treatment at $60^{\circ}$ very well although their activity is rapidly destroyed at $70^{\circ}$. By contrast, our experiments (unpublished) have shown that invertase, which also has been isolated from Neurespora (22), loses activity rapidly at $60^{\circ}$. In fact, the heat step incorporated in the purification procedure described in Iig. 1 takes advantage of this and rids the extracts of invertase activity which otherwise far exeecds that of trehalase. Similar differences in heat resistance have permitted the separation of trehalase from invertase in hog intestinal mucosa (8), and from maltase in the wax moth (16). However, there are cases where trehalase is relatively more heat sensitive than other carbohydrases (3).

A comparison of the properties of fractions 8, 11, and 12 fiom the DEAE-cellulose column reveals that the Michaelis constants are very similar ('Table II), as are the pII 
TABLE II

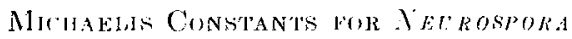
TrRHALASESS

Iata calculated by least-squares analysis of nine points.

\begin{tabular}{|c|c|c|c|}
\hline Sourie of enzyme & $\begin{array}{c}\text { Purifica- } \\
\text { tion } \\
\text { factor }^{\prime \prime}\end{array}$ & $K_{m}$ & Average \\
\hline 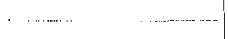 & $\ldots \ldots$ & …- & $(.,-\infty-\infty$ \\
\hline Fraction 8 & 32.6 & $3.2 \times 10^{-4}$ & \\
\hline Fraction 11 & 254 & $\begin{array}{l}6.3 \times 10^{-1} \\
5.1 \times 10^{-1}\end{array}$ & $5.7 \times 10^{4}$ \\
\hline Fratction 12 & 23 & $4.7 \times 10^{-1}$ & - \\
\hline Pooled fraction & 98 & $\begin{array}{l}4.2 \times 10^{-1} \\
2.2 \times 10^{-4} \\
1.4 \times 10^{1} \\
4.3 \times 10^{-} \\
1.7 \times 10^{-1}\end{array}$ & $2.7 \times 10^{-1}$ \\
\hline
\end{tabular}

"Purification factor defined as in Table $I$.

"Pooled fraction was obtained by mixing all fractions showing trehalase activity after two pusses through the I)HAE-cellulose column. This material was prepared during a different run than that outlined in Table I.

optima (l̈̈g. 4), substrate specificities (Table. III), and response to inhibitors. On the other hand, fraction 11 appears to behaxe differently than fraction 8 in response to incubation at $50^{\circ}$ in that its activity is increased over a period of $20 \mathrm{~min}$. at this temperature whereas that of fraction 8 is decreased. The significance of this difference is not elear in view of the similaritics in half-life of the two fractions when exposed to higher temperatures. The ponsibility must be considered that these two peaks are artifacts caused by passage through the DFAl-column inasmuch as they were recovered after the rechromatography of fraction 7 .

T'wo forms of trehalase have been reported to exist in pupae of the silkworm, Bombyr moni, on the basis of differences in elutability from DFAF-cellulose columns (24). As in the case of the enzymes from Neurospora, the silkworm trehalases were similar with respect to substrate specifieity, Michaelis constants, and $\mathrm{pH}$ optima. These situations are reminiscent of the isozymes of lactic dehydrogenase from the mouse in which no differences could be found exeept for a small one in charge and one in the isoelectric point (21). As was pointed out in the work on lactic dehydrogenases, at least five kinds of molecular changes can account for the oceurence of different but

TABSLE: III

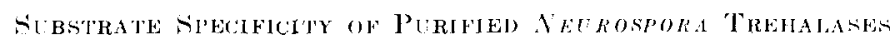

Conditions of assay are described under Mothods. All cxperiments were run in triplieate except for the maltose samples of fractions 11 and 12 .

\begin{tabular}{|c|c|c|c|c|c|c|c|c|c|}
\hline \multirow{5}{*}{ Substiate } & \multicolumn{9}{|c|}{ Fration number } \\
\hline & \multicolumn{3}{|c|}{$8^{\prime \prime}$} & \multicolumn{3}{|c|}{11} & \multicolumn{3}{|c|}{12} \\
\hline & \multicolumn{2}{|c|}{ O, tical density } & Gilucose & \multicolumn{2}{|c|}{ Optical density } & \multirow[b]{2}{*}{$\begin{array}{l}\text { Gilucose } \\
\text { produced } \\
0.1 \mathrm{ml} \text {. } \\
\text { enayme }\end{array}$} & \multicolumn{2}{|c|}{ Optical density } & Gilucose \\
\hline & $\begin{array}{l}\text { Enzyme } \\
+ \text { sub. }\end{array}$ & $\begin{array}{c}\text { Sub. } \\
\text { control }\end{array}$ & $\begin{array}{l}\text { produced, } \\
0.1 \mathrm{ml} \\
\text { enzyme }\end{array}$ & $\begin{array}{l}\text { Enzyme } \\
\text { + sub. }\end{array}$ & sub. & & $\underset{\substack{\text { Enzyme } \\
+x i b .}}{.}$ & siubs. & $\begin{array}{c}\text { producenl' } \\
0.2 \mathrm{ml} \\
\text { cmame }\end{array}$ \\
\hline & & & $m s$ & & & $m_{s}$ & & & $m_{S}$ \\
\hline Trebilose & .319 & .203 & 23.1 & $.578^{n} \times+$ & $.288^{\prime \prime}$ & 240.0 & $.425^{\prime \prime}$ & $.288^{\prime \prime}$ & 27.5 \\
\hline Sincrose & .023 & .019 & 0.8 & .075 & .078 & 0 & .164 & .078 & 5.8 \\
\hline Luctose & .023 & .016 & 1,4 & .054 & .050 & 0) & .065 & $.05 i$ & 1.8 \\
\hline Melibiose: & .0012 & .059 & 0.6 & .181 & .193 & 0 & .207 & .193 & 3.6 \\
\hline Ratfinose & .002 & .001 & 0) & .053 & .047 & 1.2 & .058 & .047 & 2.2 \\
\hline Waltose? & .372 & .373 & 0 & $.415^{\prime \prime}$ & $.425^{n}$ & 0 & $.3666^{\circ}$ & $.425^{\prime \prime}$ & 0 \\
\hline C'ellobiose? & .129 & .159 & 0 & .245 & .240 & 0.1 & $2(i 3)$ & .240 & $4.1 i$ \\
\hline
\end{tabular}

"Incubated in the presence of glueose oxidase for 10 min.

1. 3.6 6 - $1 \mu \mathrm{g}$. protein $/ 0.1 \mathrm{ml}$. enzyme assityed.

c:3.155 ug. protein/0.1 ml. enzyme assityed.

a $4.0+0 \mu g$. protein $/ 0.2 \mathrm{ml}$. engime assuged. 


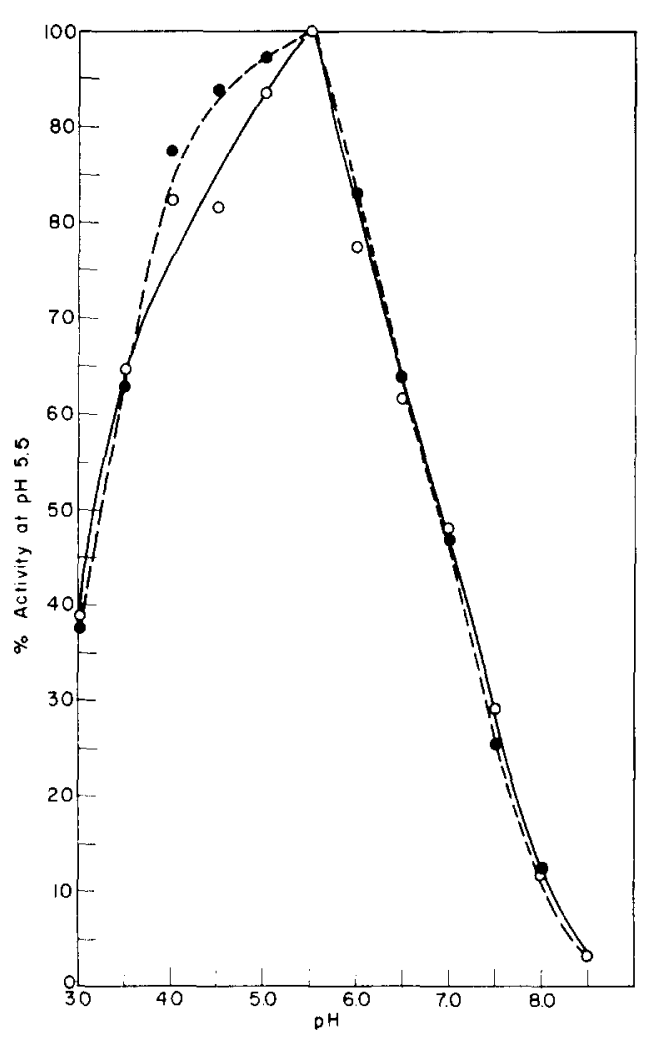

Fici, 4. Effect of pH upon trehalase eluted in fraction 8 (dotted line) and fration 11 (solid line). Conditions of assay are described in text.

closely related isozymes. Studies of the several fractions from Neurospora which show trehalase activity are being continued in order to determine the significance of the differences between them in terms of the types of molecular changes mentioned above.

\section{REFETENCHS}

1. Buock, H., axo Sildiman, H., Expertentia 1, 94 (1945).

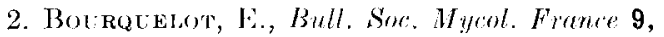
11 (1893).

3. Bourovedot, L., Compt. Rend. 116, 826 (1893),

4. Bourglelo'T, H., ANo Herissey, H., ('ompt. Rend. 139, 874 (1904).

5. CLeGG, J. S., Biol. Bull. 123, 295 (1962). (i. Colntors, J. H., Petek, F., and KolahiZanorzt, M. A., Bull. Sor: Chim. Biol. 44, $735(1962)$.

7. Courtols, J. E., Pelek, F. ANo 'To-I)ong, Bull. Sor. Chim. Biol. 44, 11 (1942)

8. I)AHrqust, A., 1eta Chem. Soand. 13, 945 (1959)

9. I) AHlQCist, A., Arla ('hem. Sramel. 14, 9 (1960).

10. Fischer, H., Ber. 28, 1429 (1895).

11. Fitzgeralis, R.., and Bernheim, J Barteriol. $55,677(1948)$.

12. Frerejacole, M., Compl. Rend. 213, 88 (1941).

13. Frimoman, Á, Areh. Biochem. Biophys. 87, $252(1900)$.

14. Howom, G. F., Axn Kinzy, B. A., Chem. Ind. 1956, $1453(1956)$.

15. Iwanofr, N. N., Biochem. Z. 162, 455 (1925).

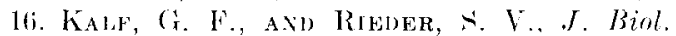
('hem. 230, 691 (1958).

17. Kescon, A. S., Abstr. p. 31r. Amer. Chem. Soe., Jiv. Biol, Chem., April 1956.

18. Ijngapea, B. T., and Sussmax, A. S., Plant Physiol. 34, 466(1959).

19. Lowry, 0. H., Rosebrolgh, X. J., Farr, A. I., anil Randall, R. I., I. Biol. Chem. 156, $121(1944)$.

20. Takes, T. M., and Phafr, H. J., Intomite man Leeuwenhok .J. Microbiol. Serol. 18, 323 (1952).

21. Marker't, C. I.., ann Appelat, F., Ann. N. Y. Acal. Sui. 94, (778 (1961).

22. Metzenbert, R. I., Arch. Biochem. Biophys. 96, $468(1962)$.

23. Мүввӓск, К., Eryeh. Enzymforsch. 10, 269 (1949).

24. SalTo, ., J. Biorhem. (Japan) 48, 101 (1960).

25. Aomorit, M., J. Riol. (hem. 195, 19) (1952).

26. Sissmax, A. S., Quart. Rev. Biol. 36, 109 (1961).

27. Sismmax, A. S., anil Itanapla, B. 'T., Sience $130,1343(1959)$.

28. Vores, H. J., Microbial Genelic's Bull. 13, 42 (195(j).

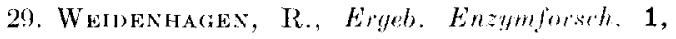
1168 (1932).

30. Went, F. A. F. C., Jahrb. Wiss. Botan. 36, (i11 (1901).

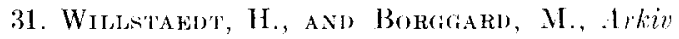
Kemi, Mineral. Geol. B23, 1 (1946).

32. Wrat'l, (i. R., ANi) KaLF, (i. F., I. Gen. Physiol. 40, 833 (1957).

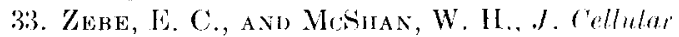
(omp. Physiol. 53, $21(1959)$ 